\title{
Glucagon-Like Peptide-I Exerts Anti-Inflammatory Effects On Mouse Colon Smooth Muscle Cells Through The Cyclic Adenosine Monophosphate/Nuclear Factor- $\kappa B$ Pathway In Vitro [Corrigendum]
}

\begin{abstract}
Al-Dwairi A, Alqudah TE, Al-Shboul O, Alqudah M, Mustafa AG, Alfaqih MA. J Inflamm Res. 2018;11:95-109.

Ayman G Mustafa has advised that by error he omitted one of the affiliations that he was associated with when he conducted this study. The correct author and affiliations list should appear as follows:
\end{abstract}

Ahmed Al-Dwairi, ${ }^{1}$ Tamara E Alqudah, ${ }^{1}$ Othman AlShboul, ${ }^{1}$ Mohammad Alqudah, ${ }^{1}$ Ayman G Mustafa, ${ }^{2,3}$ Mahmoud A Alfaqih ${ }^{1}$
${ }^{1}$ Department of Physiology and Biochemistry, Faculty of Medicine, Jordan University of Science and Technology, Irbid, Jordan; ${ }^{2}$ Department of Anatomy, Faculty of Medicine, Jordan University of Science and Technology, Irbid, Jordan; ${ }^{3}$ Department of Basic Medical Sciences, College of Medicine, Qatar University, Doha, Qatar
Journal of Inflammation Research

\section{Publish your work in this journal}

The Journal of Inflammation Research is an international, peerreviewed open-access journal that welcomes laboratory and clinical findings on the molecular basis, cell biology and pharmacology of inflammation including original research, reviews, symposium reports, hypothesis formation and commentaries on: acute/chronic inflammation; mediators of inflammation; cellular processes; molecular

\section{Dovepress}

mechanisms; pharmacology and novel anti-inflammatory drugs; clinical conditions involving inflammation. The manuscript management system is completely online and includes a very quick and fair peerreview system. Visit http://www.dovepress.com/testimonials.php to read real quotes from published authors. 